\title{
NET PRIMARY PRODUCTIVITY OF SUBALPINE MEADOWS IN YOSEMITE NATIONAL PARK IN RELATION TO CLIMATE VARIABILITY
}

\author{
Peggy E. Moore1,7, Jan W. van Wagtendonk1, Julie L. Yee², Mitchel P. McClaran³, \\ David N. Cole ${ }^{4}$, Neil K. McDougald ${ }^{5}$, and Matthew L. Brooks ${ }^{6}$
}

\begin{abstract}
Subalpine meadows are some of the most ecologically important components of mountain landscapes, and primary productivity is important to the maintenance of meadow functions. Understanding how changes in primary productivity are associated with variability in moisture and temperature will become increasingly important with current and anticipated changes in climate. Our objective was to describe patterns and variability in aboveground live vascular plant biomass in relation to climatic factors. We harvested aboveground biomass at peak growth from four $64-\mathrm{m}^{2}$ plots each in xeric, mesic, and hydric meadows annually from 1994 to 2000. Data from nearby weather stations provided independent variables of spring snow water content, snow-free date, and thawing degree days for a cumulative index of available energy. We assembled these climatic variables into a set of mixed effects analysis of covariance models to evaluate their relationships with annual aboveground net primary productivity (ANPP), and we used an information theoretic approach to compare the quality of fit among candidate models. ANPP in the xeric meadow was negatively related to snow water content and thawing degree days and in the mesic meadow was negatively related to snow water content. Relationships between ANPP and these 2 covariates in the hydric meadow were not significant. Increasing snow water content may limit ANPP in these meadows if anaerobic conditions delay microbial activity and nutrient availability. Increased thawing degree days may limit ANPP in xeric meadows by prematurely depleting soil moisture. Large withinyear variation of ANPP in the hydric meadow limited sensitivity to the climatic variables. These relationships suggest that, under projected warmer and drier conditions, ANPP will increase in mesic meadows but remain unchanged in xeric meadows because declines associated with increased temperatures would offset the increases from decreased snow water content.
\end{abstract}

RESUMEN.—Las praderas subalpinas son algunos de los componentes de mayor importancia ecológica de los paisajes de montaña, y la productividad primaria es importante para mantener las funciones de la pradera. El comprender de qué manera se asocian los cambios de la productividad primaria con la variabilidad de la humedad y la temperatura será cada vez más importante por los cambios climáticos actuales y los que se pronostican. Nuestro objetivo fue describir los patrones de biomasa de las plantas vasculares vivas sobre el nivel de la tierra y su variabilidad en relación con los factores climáticos. Extrajimos biomasa sobre el nivel de la tierra, en su punto máximo de crecimiento, de cuatro terrenos de $64 \mathrm{~m}^{2}$ cada uno, de praderas áridas, secas y húmedas, anualmente, entre el año 1994 y el año 2000. Las estaciones meteorológicas cercanas proporcionaron información sobre las variables independientes del contenido de agua proveniente de la nieve de primavera, las épocas sin nieve y el grado de deshielo por día para un índice acumulativo de energía disponible. Reunimos estas variables climáticas en un análisis de covarianza de efectos mixtos para evaluar sus relaciones con la productividad primaria neta anual sobre el nivel de la tierra (ANPP = annual net primary productivity), y utilizamos un enfoque teórico de la información para evaluar cuál de los modelos candidatos se ajusta mejor. La ANPP de la pradera árida se relacionó con el contenido de agua de nieve y el grado por día de descongelamiento de manera negativa. En la pradera seca, la ANPP se relacionó con el contenido de agua de nieve de manera negativa. Las relaciones entre la ANPP y estas dos covariables no fueron significativas en la pradera húmeda. El incremento del contenido de agua de nieve puede restringir la ANPP en estas praderas si las condiciones anaeróbicas hacen que se deteriore la actividad microbiana y la disponibilidad de nutrientes. El incremento del grado por día de descongelamiento puede limitar la ANPP en las praderas áridas haciendo que la humedad del suelo disminuya de manera prematura. La gran variación de la ANPP en la pradera húmeda en el transcurso del año restringió la sensibilidad a las variables climáticas. Estas relaciones sugieren que, bajo las condiciones más cálidas y más secas que se pronostican, la ANPP se incrementará en las praderas secas, pero se mantendrá sin cambios en las praderas áridas porque las disminuciones asociadas con el aumento de la temperatura compensarían el contenido de agua de nieve que registró una disminución.

In the Sierra Nevada of California, subalpine meadows are some of the most scenic and eco- logically important components of the landscape. Although they occupy $<3 \%$ of the range,

\footnotetext{
${ }^{1}$ U.S. Geological Survey, Western Ecological Research Center, Yosemite Field Station, 5083 Foresta Road, El Portal, CA 95318.

${ }^{2}$ U.S. Geological Survey, Western Ecological Research Center, 3020 State University Drive E, Modoc Hall, Suite 3006, Sacramento, CA 95819.

${ }^{3}$ University of Arizona, School of Natural Resources and the Environment, 325 Biosciences East, Tucson, AZ 85721.

${ }_{4}^{4}$ Aldo Leopold Wilderness Research Institute, 790 E. Beckwith, Box 8089, Missoula, MT 59807

5 University of California Cooperative Extension, 328 S Madera Avenue, Madera, CA 93637.

${ }^{6}$ U.S. Geological Survey, Western Ecological Research Center, Yosemite Field Station, 40298 Junction Drive, Suite A, Oakhurst, CA 93644

7E-mail: peggy_moore@usgs.gov
} 
subalpine meadows provide essential ecosystem structure and functions. These include biogeochemical cycling, hydrologic functions (e.g., flood attenuation), maintenance of biodiversity, sediment retention, carbon sequestration, wildlife forage production, and habitat structure (Smith et al. 1995, Hruby 2009, Morton and Pereyra 2010). Meadows in the Sierra Nevada are receiving increased attention both for the ecosystem functions they provide and for the socioeconomic values related to their proper use (e.g., aesthetics, domestic animal grazing; Roche et al. 2012).

Aboveground net primary productivity (ANPP) is one important measure of biological system performance and a provider of critical ecosystem services. ANPP is the engine for converting light, water, and nutrients into organic soils that cycle nutrients and moderate the movement of soil water through the system. Aboveground growth provides the structure and composition that characterizes vertebrate and invertebrate forage and breeding habitat (Morton and Pereyra 2010, Holmquist et al. 2011). Patterns of ANPP likely underestimate total net primary production given high root: shoot ratios. In similar systems, belowground productivity has outpaced aboveground growth (Chapin et al. 1993, Fisk et al. 1998, Hobbie and Chapin 1998), but logistical constraints prevented us from measuring belowground production or water table depth.

Understanding how changes in primary productivity are associated with variability in moisture and temperature will become increasingly important with current and anticipated changes in climate variability. Forecasts for the 21 st century under greenhouse gas emission scenarios are for higher temperatures and reduced snowpack. Under the lowest emission scenario of the Intergovernmental Panel on Climate Change (IPCC), the B1 scenario, 1 April snow water content is projected to decline by $34 \%$ between $2000 \mathrm{~m}$ and $3000 \mathrm{~m}$ elevation in the Sierra Nevada, and mean summer temperature is projected to increase 1.2 ${ }^{\circ} \mathrm{C}$ by the middle of the century (2020-2049; Hayhoe et al. 2004). By late in the century (2070-2099), snowpack in the Sierra Nevada is projected to decline by $30 \%-90 \%$. These projections are consistent with projections for mountainous areas throughout the western United States (Mote et al. 2005, Maurer et al. 2007, Barnett et al. 2008).
The effects of climate variability vary among meadow types. Changes in mesic and xeric meadow productivity differ in response to increased $\mathrm{N}$ availability, which results from temperature-mediated increases in $\mathrm{N}$ mineralization (Bowman et al. 1995), and the response is greater in colder environments (Rustad et al. 2001). Hydric meadows can be expected to be less sensitive to changes in mean annual moisture input than xeric meadows (Hsu et al. 2012).

We examined ANPP for 7 years within 3 subalpine meadows in Yosemite National Park in the central Sierra Nevada of California with differing moisture regimes and species assemblages. Our objective was to describe patterns in aboveground live vascular plant biomass and the relationship of that biomass to climatic variability. We hypothesize that current-year cumulative growing season warmth, growing season length, and current-year total precipitation will be significant predictors of ANPP, but the relative importance and possibly the direction of these relationships will vary among the xeric, mesic, and hydric meadows.

\section{Methods}

\section{Study Area}

The study system consisted of 3 meadows with differing moisture regimes and species assemblages. Ratliff (1982) defined 21 vegetative series occurring in montane and subalpine meadows in the Sierra Nevada on the basis of vegetation composition. The present work focused on 3 of the most common series arrayed among 3 moisture regimes in meadows of Yosemite National Park (Fig. 1).

Yosemite National Park lies in a Mediterranean-type climate region with warm, dry summers and cool to cold, moist winters. The mean minimum temperature in January at Tuolumne Meadows, the middle elevation study site (2620 m elevation), is $-12.7^{\circ} \mathrm{C}$, and the mean maximum in July is $21.3^{\circ} \mathrm{C}$ (WRCC 2011). Precipitation falls predominantly in the form of snow and is concentrated in the winter months from October through March. Average annual precipitation is $755 \mathrm{~mm}$ at Tuolumne Meadows (minimum during the study $=599$ $\mathrm{mm}$ in 1994 [79\% of average], maximum during the study $=1168 \mathrm{~mm}$ in 1995 [155\% of average]). 


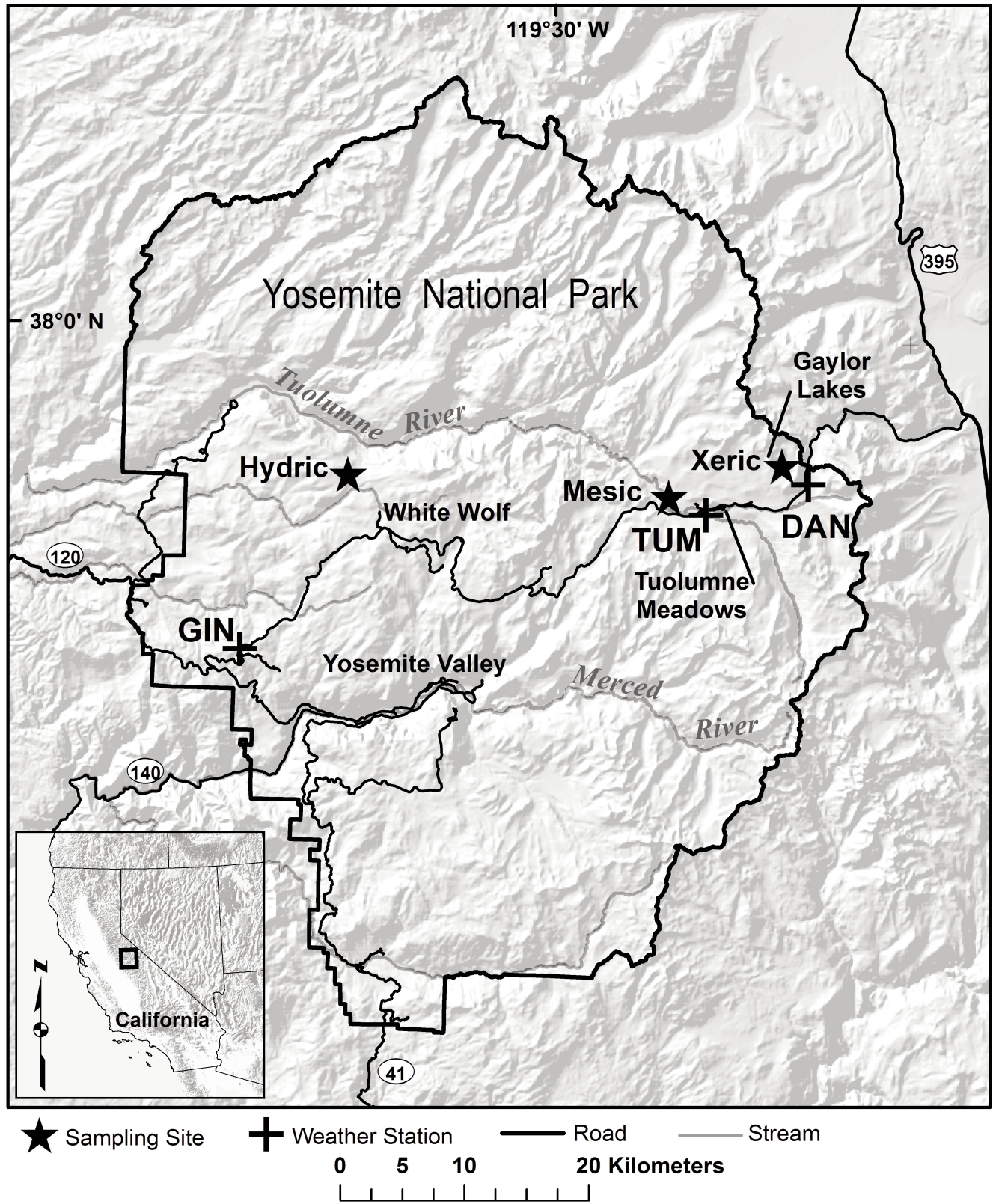

Fig. 1. Study sites consisted of 3 meadows ranging in elevation from 2280 to $3100 \mathrm{~m}$ within Yosemite National Park, central Sierra Nevada, California. Sources of weather data were California State Department of Water Resources weather stations at Dana Meadow (DAN) for the xeric meadow, Tuolumne Meadows (TUM) for the mesic meadow, and Gin Flat (GIN) for the hydric meadow.

Our xeric site is characterized by the shorthair sedge (Carex filifolia Nutt. var. erostrata Kük. [synonym Carex exserta Mack.]) series, which dominates on open, rocky, south- and west-facing slopes and flats between $2600 \mathrm{~m}$ and $3500 \mathrm{~m}$ elevation. Substrates are typically sandy, gravelly loams on the upper margins of meadows or just beyond the zone of seasonal soil saturation (NatureServe 2011). Soils are strongly acidic, with $\mathrm{pH}$ about 5.1 (Ratliff 1982). Vegetation is typically sparse cover of fine foliage over a sandy substrate (Fig. 2a). 


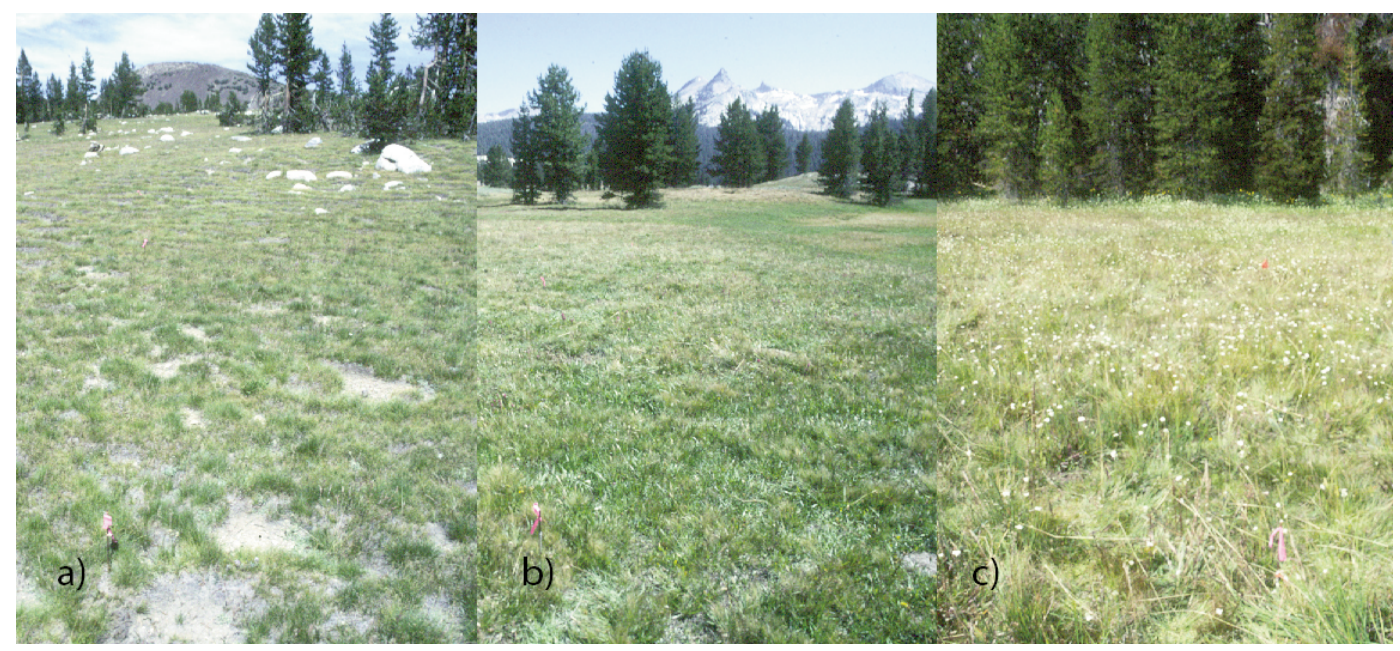

Fig. 2. The vegetation of (a) xeric meadow (shorthair sedge [Carex filifolia var. erostrata] series), (b) mesic meadow (Muir's reed grass [Calamagrostis muiriana] series), and (c) hydric meadow (tufted hair grass [Deschampsia cespitosa] series) sampled for aboveground net primary productivity.

Foliar cover averages $50 \%$, with shorthair sedge accounting for $72 \%$ of vegetative cover. Species richness is low (Ratliff 1982), and only 20 plant species occurred within the four 64$\mathrm{m}^{2}$ plots sampled in the current study. Common associates of shorthair sedge in our plots included Solidago multiradiata Aiton, Micranthes aprica (Greene) Small, Poa stebbinsii Soreng, Rumex paucifolius Nutt., and Antennaria media Greene. Our xeric site was located at $3100 \mathrm{~m}$ in the Gaylor Lakes basin near Tioga Pass $\left(37^{\circ} 54^{\prime} 30^{\prime \prime} \mathrm{N}, 119^{\circ} 17^{\prime} 4^{\prime \prime} \mathrm{W}\right)$ (Klikoff 1965, Cole et al. 2004).

Our mesic site is characterized by the Muir's reed grass (Calamagrostis muiriana B.L. Wilson \& Sami Gray [synonym C. breweri]) series, which occurs on very gentle lower slopes and basin floors to slopes between $2440 \mathrm{~m}$ and $3170 \mathrm{~m}$ elevation (NatureServe 2011). Substrates are typically sandy to silt loams that are seasonally saturated and usually have perennial subsurface moisture. Soils are acidic ( $\mathrm{pH} 5.0)$ and typically have $<10 \%$ organic matter content (Ratliff 1982). Even though the mesic site is dominated by short $(<15 \mathrm{~cm})$ tufted grasses, particularly Muir's reed grass (45\% of vegetative cover) (Fig. $2 \mathrm{~b}$ ), species richness is relatively high, with 40 plant species occurring in the four $64-\mathrm{m}^{2}$ plots in the current study. The common associates we observed in Muir's reed grass plots were Danthonia intermedia Vasey ssp. inter- media, Oreostemma alpigenum (Torr. \& A. Gray) Greene var. andersonii (A. Gray) G.L. Nesom, Vaccinium cespitosum Michx., Gentianopsis holopetala (A. Gray) H.H. Iltis, Senecio scorzonella Greene, Viola adunca Sm. ssp. adunca, Trifolium monanthum A. Gray ssp. monanthum, and Carex subnigricans Stacey. Our mesic site was located at $2600 \mathrm{~m}$ near Delaney Creek in Tuolumne Meadows (37 $52^{\prime}$ $\left.57^{\prime \prime} \mathrm{N}, 119^{\circ} 23^{\prime} 1^{\prime \prime} \mathrm{W}\right)$.

Our hydric site is characterized by the tufted hair grass (Deschampsia cespitosa (L.) P. Beauv. ssp. cespitosa) series, which forms dense stands with $60 \%-90 \%$ cover (Fig. 2c). Tufted hair grass occurs on basin floors and benches between $1830 \mathrm{~m}$ and $3200 \mathrm{~m}$ elevation. Stands occupy seasonally flooded to saturated sandy to silty loams and mucks. Soils are acidic and typically have low organic matter content (Ratliff 1982). This series is species rich, with 42 plant species occurring in the three $64-\mathrm{m}^{2}$ plots sampled. Common associates of tufted hair grass included Bistorta bistortoides (Pursh) Small, Carex luzulina Olney, Carex abrupta Mack., Muhlenbergia filiformis (S. Watson) Rydb., Symphyotrichum spathulatum (Lindl.) G.L. Nesom var. spathulatum, Eleocharis quinqueflora (Hartmann) O. Schwarz, and Hypericum anagalloides Cham. \& Schltdl. Our hydric site was located at $2280 \mathrm{~m}$ adjacent to Harden Lake and approximately $4.8 \mathrm{~km}$ north of White Wolf $\left(37^{\circ} 53^{\prime} 43^{\prime \prime} \mathrm{N}, 119^{\circ} 40^{\prime} 44^{\prime \prime} \mathrm{W}\right)$. 


\section{Aboveground Net Primary Productivity}

We established four $8 \times 8$-m plots in the xeric meadow, 4 plots in the mesic meadow, and 3 plots in the hydric meadow. The minimum distance between plots within each meadow was $32 \mathrm{~m}$. No domestic animal grazing occurred in the meadows during the study or for several decades prior; wildlife had access to plots, but there was no sign of wildlife grazing during the study. We harvested live aboveground biomass from 10 randomly located $0.125-\mathrm{m}^{2}(35.35 \times 35.35-\mathrm{cm})$ subplots within each plot during each year from 1994 to 2000 . We marked plots and mapped subplots precisely to avoid repeated clipping in the same subplots in subsequent years. The procedure for estimating biomass consisted of clipping vegetation to a height of approximately $1 \mathrm{~cm}$ above the ground surface, separating live biomass from litter and standing dead biomass, drying samples at $60{ }^{\circ} \mathrm{C}$ to a constant weight, and recording weights to the nearest $0.1 \mathrm{~g}$. We timed collections each year within each meadow to coincide with peak biomass following flowering and prior to senescence. No live aboveground stems overwinter in these meadows, and herbivory and decomposition are relatively low. Thus, we consider peak aboveground plant biomass to be a close proxy for ANPP.

\section{Climatic Data}

We obtained daily temperature $\left({ }^{\circ} \mathrm{C}\right)$ and snow water content $(\mathrm{mm})$ data from the California Data Exchange Center (CDWR 2011) for California State Department of Water Resources weather stations located closest to sampling sites. For the xeric site, we used the Dana Meadows station $2.5 \mathrm{~km}$ southeast; for the mesic site, we used the Tuolumne Meadows station $3.3 \mathrm{~km}$ southeast; and for the hydric site, we used the Gin Flat station 16.5 $\mathrm{km}$ southwest. Weather stations were within 12-130 m elevation of, within about $45^{\circ}$ aspect of, and similar in steepness (most were level) and slope position to sampling sites so that topographic influences were similar.

We represented annual climate variables with combinations of precipitation (1 April snow water content for the current year $\left[A p r 1 S W C_{c y}\right], 1$ April snow water content for the previous year $\left.\left[\mathrm{Apr}_{\mathrm{S}} \mathrm{SWC}_{\mathrm{py}}\right]\right)$ and temperature (thawing degree days of the current year from snowmelt to harvest $\left[\mathrm{TDD}_{\mathrm{s}-\mathrm{h}}\right]$, thawing degree days of the previous year [snowmelt to end of growing season, $\left.\mathrm{TDD}_{\mathrm{py}}\right]$ ). The 1 April snow water content represents potential soil moisture inputs during the majority of the growing season. Thawing degree days is a cumulative index of the energy available for melting snow or growing plants (Walker et al. 1994). We calculated TDD from daily temperatures as the sum of mean daily temperatures for all days when the mean temperature was above $0{ }^{\circ} \mathrm{C}$. We represented growing season length with snow-free date (SFD) expressed as Julian date beginning with 1 January, because SFD has the greatest influence on the length of time between initiation of meadow plant growth in the spring and plant senescence at the end of the season (Billings and Bliss 1959, Galen and Stanton 1993).

\section{Statistical Analysis}

We expected that snow water content $\left(A_{p r 1 S W C}, A_{\text {cy }}\right.$ AprlSWC $C_{p y}$ ), growing season length (represented by SFD), and growing season warmth $\left(\mathrm{TDD}_{\mathrm{s}-\mathrm{h}}, \mathrm{TDD}_{\mathrm{py}}\right)$ would have varying influence on ANPP in the meadows. Therefore, we assembled a set of mixed effects analysis of covariance (ANCOVA) models based on hypotheses about how climatic factors affect ANPP at the plot level (Table 2). Then we used Akaike's information criterion adjusted for small sample size $\left(\mathrm{AIC}_{c}\right)$ to compare the quality of fit among candidate models. We selected the best among the hypothesized models based on the lowest $\mathrm{AIC}_{c}$ value, particularly when all other models had $\mathrm{AIC}_{c}$ difference $\left(\Delta \mathrm{AIC}_{c}\right)>2$ (Burnham and Anderson 2002). Because we expected meadow type (Type) to determine the overall magnitude of aboveground plant growth (Cole et al. 2004), we included Type alone as a categorical variable in the null model identified as xeric, mesic, or hydric meadow. We included available climatic variables, listed above, as fixed effects to explain additional systematic variations, and we treated mean ANPP $\left(\mathrm{g} \cdot \mathrm{m}^{-2}\right)$ at the plot level as our sampling unit for analysis.

We modeled 77 observations of ANPP (11 plots for 7 years) on a natural-log scale due to heteroscedastic distribution of residuals based on a global model that included all fixed effects, year and plot as random categorical effects, and all 2-way interactions between meadow type and other variables in order to allow climatic effects to differ among the 3 
TABLE 1. Aboveground net primary productivity (ANPP) of xeric, mesic, and hydric meadows within Yosemite National Park, California. $\mathrm{SWC}_{\mathrm{cy}}=1$ April snow water content for the current year; $\mathrm{SWC}_{\mathrm{py}}=1$ April snow water content for the previous year; $\mathrm{SFD}=$ snow-free date; $\mathrm{TDD}=$ thawing degree days $=$ sum of the mean daily temperature for all days with temperatures above $0{ }^{\circ} \mathrm{C}$; $\mathrm{TDD}_{s-h}=$ thawing degree days from snowmelt to date of harvest of aboveground biomass; $\mathrm{TDD}_{\mathrm{py}}=$ thawing degree days for the previous year from snowmelt to end of growing season.

\begin{tabular}{|c|c|c|c|c|c|c|c|}
\hline Meadow type & Year & $\begin{array}{l}\text { ANPP } \\
\left(\mathrm{g} \cdot \mathrm{m}^{-2}\right)\end{array}$ & $\begin{array}{l}\mathrm{SWC}_{\mathrm{cy}} \\
(\mathrm{mm})\end{array}$ & $\begin{array}{l}\mathrm{SWC}_{\mathrm{py}} \\
(\mathrm{mm})\end{array}$ & SFD & $\begin{array}{l}\mathrm{TDD}_{\mathrm{s}-\mathrm{h}} \\
\left({ }^{\circ} \mathrm{C}\right)\end{array}$ & $\begin{array}{l}\mathrm{TDD}_{\mathrm{py}} \\
\left({ }^{\circ} \mathrm{C}\right)\end{array}$ \\
\hline $\begin{array}{l}\text { Xeric (Carex filifolia var. } \\
\text { erostrata } \text { series) }\end{array}$ & $\begin{array}{r}1994 \\
1995 \\
1996 \\
1997 \\
1998 \\
1999 \\
2000 \\
\text { Mean }\end{array}$ & $\begin{array}{l}77.0 \\
58.0 \\
72.2 \\
66.5 \\
77.6 \\
95.3 \\
96.6 \\
77.6\end{array}$ & $\begin{array}{r}404 \\
1156 \\
863 \\
935 \\
1029 \\
714 \\
647 \\
821\end{array}$ & $\begin{array}{r}950 \\
404 \\
1156 \\
863 \\
935 \\
1029 \\
714 \\
864\end{array}$ & $\begin{array}{l}145 \\
192 \\
157 \\
152 \\
188 \\
163 \\
151 \\
\mathbf{1 6 4}\end{array}$ & $\begin{array}{r}1462 \\
429 \\
1059 \\
404 \\
487 \\
451 \\
411 \\
\mathbf{6 7 2}\end{array}$ & $\begin{array}{r}1262 \\
1909 \\
524 \\
2016 \\
803 \\
637 \\
785 \\
1134\end{array}$ \\
\hline $\begin{array}{l}\text { Mesic (Calamagrostis } \\
\text { muiriana } \text { series) }\end{array}$ & $\begin{array}{r}1994 \\
1995 \\
1996 \\
1997 \\
1998 \\
1999 \\
2000 \\
\text { Mean }\end{array}$ & $\begin{array}{l}368.9 \\
164.8 \\
193.7 \\
199.5 \\
165.7 \\
198.0 \\
202.2 \\
213.3\end{array}$ & $\begin{array}{l}259 \\
847 \\
573 \\
643 \\
887 \\
543 \\
469 \\
603\end{array}$ & $\begin{array}{l}823 \\
259 \\
847 \\
573 \\
643 \\
887 \\
543 \\
654\end{array}$ & $\begin{array}{l}114 \\
173 \\
134 \\
131 \\
169 \\
141 \\
130 \\
142\end{array}$ & $\begin{array}{l}991 \\
949 \\
853 \\
808 \\
720 \\
812 \\
854 \\
855\end{array}$ & $\begin{array}{r}825 \\
1299 \\
949 \\
1174 \\
1123 \\
859 \\
1050 \\
1040\end{array}$ \\
\hline $\begin{array}{l}\text { Hydric (Deschampsia } \\
\text { cespitosa ssp. cespi- } \\
\text { tosa } \text { series) }\end{array}$ & $\begin{array}{r}1994 \\
1995 \\
1996 \\
1997 \\
1998 \\
1999 \\
2000 \\
\text { Mean }\end{array}$ & $\begin{array}{l}445.9 \\
282.3 \\
388.2 \\
420.2 \\
313.3 \\
316.1 \\
363.7 \\
361.4\end{array}$ & $\begin{array}{r}424 \\
1155 \\
594 \\
676 \\
1024 \\
646 \\
451 \\
710\end{array}$ & $\begin{array}{r}1155 \\
424 \\
1155 \\
594 \\
676 \\
1024 \\
646 \\
811\end{array}$ & $\begin{array}{l}134 \\
175 \\
136 \\
127 \\
178 \\
144 \\
131 \\
146\end{array}$ & $\begin{array}{l}1621 \\
1510 \\
1685 \\
1671 \\
1426 \\
1344 \\
1579 \\
1548\end{array}$ & $\begin{array}{l}1324 \\
1723 \\
1205 \\
1769 \\
1772 \\
1224 \\
1494 \\
1502\end{array}$ \\
\hline
\end{tabular}

meadows. Prior to comparisons among hypothesized models and a null model without climatic effects, we analyzed the effects of plot and year nested within meadow type to account for correlations among temporally and spatially repeated measurements (i.e., same plot at different years or plots nested in the same meadow within a year). We determined whether the correlations were modeled best by categorizing random effects based on plots, years, both, or neither. We used PROC MIXED in SAS 9.2 for all analyses and report $\mathrm{AIC}_{c}$ and Akaike weights as relative weights of evidence supporting the different models (Littell et al. 1996, SAS Institute, Inc. 2007). We used restricted and regular maximum likelihood techniques (REML and ML) to perform the initial comparison of random effects and the final comparison of covariates, respectively, and we present final estimates using REML (Zuur et al. 2009). To quantify model fit, we calculated $\mathrm{R}^{2}$ values as the proportion of ANPP variation explained by the model (i.e., with climatic covariates) as compared to the null model that is based on only meadow type and random plot and year effects. Specifically,

$$
\mathrm{R}^{2}=\left(\mathrm{SSE}_{0}-\mathrm{SSE}_{\mathrm{m}}\right) / \mathrm{SSE}_{0},
$$

where $\mathrm{SSE}_{0}$ and $\mathrm{SSE}_{\mathrm{m}}$ are the sum of squared residual errors from the null and climate models, respectively.

Using the model with the greatest support (i.e. smallest $\mathrm{AIC}_{c}$ ), we estimated the covariate relationships with ANPP based on each model coefficient, $\beta$, which represents change in mean ANPP, on the natural-log scale, per unit increase in the covariate. We calculated the percent change in estimated mean ANPP (natural-log scale) per 100 units covariate increase (e.g., $100 \mathrm{~mm}$ increase in snow water content or $100{ }^{\circ} \mathrm{C}$ increase in thawing degree days) by using the formula $\exp (100 \beta)-100 \%$.

\section{RESUlTS}

Mean ANPP increased from xeric to hydric sites, paralleling gradients of soil moisture (from dry to wet) and elevation (from high to low). The 7 -year mean ANPP was $77 \mathrm{~g} \cdot \mathrm{m}^{-2}(\mathrm{SE}$ 5.4) for the xeric site, $213 \mathrm{~g} \cdot \mathrm{m}^{-2}$ (SE 26.6) for the mesic site, and $361 \mathrm{~g} \cdot \mathrm{m}^{-2}$ (SE 22.9) for the hydric site (Table 1). The 7-year mean 


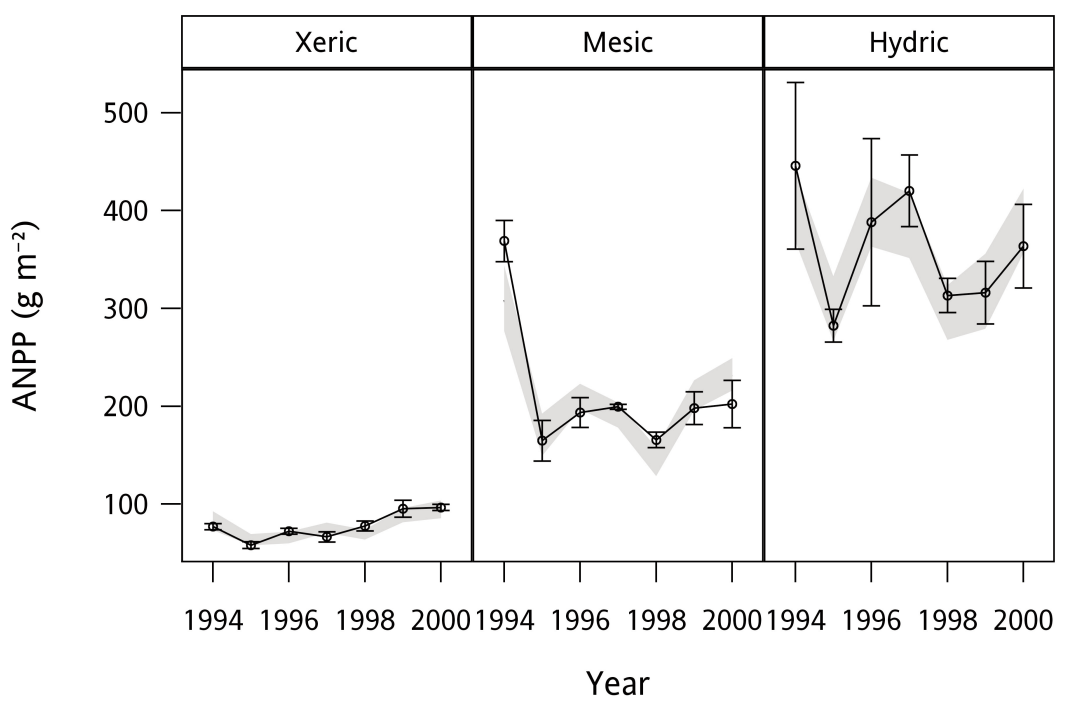

Fig. 3. Fitted values \pm 1 SE (shaded band) overlaid against actual data \pm 1 SE (line graph with vertical bars) for aboveground net primary productivity (ANPP) of subalpine meadows in Yosemite National Park, California, 1994-2000.

Apr1SWC was $821 \mathrm{~mm}$ (SE 95) for the xeric site, $603 \mathrm{~mm}$ (SE 82) for the mesic site, and $710 \mathrm{~mm}$ (SE 105) for the hydric site. TDD varied among years and meadows with a mean at the xeric site (672 degree days, SE 158) less than half that of the hydric site (1548 degree days, SE 48). The later mean SFD at the xeric site (13 June [ \pm 7 days] vs. 22 May for the mesic site and 26 May for the hydric site) reflects the meadow's high elevation. The greater Apr1SWC in the higher-elevation xeric meadow is probably a function of lower TDD values delaying snowmelt relative to the other meadows.

Interannual variation in ANPP was greater at the mesic site (CV 34\%) than at the xeric site (CV 19\%) or the hydric site (CV 17\%), but within-year variation was greatest in the hydric and least in the xeric meadow (Fig. 3). The AprlSWC for the xeric site ranged from $404 \mathrm{~mm}$ in 1994 to $1156 \mathrm{~mm}$ in 1995 (CV $32 \%$ ), a nearly 3 -fold difference. The SFD varied by as much as 59 days (CV 16\%) at the mesic site and 47 days (CV 12\%) at the xeric site.

Patterns in the response of ANPP to annual weather patterns were generally consistent, with lower ANPP levels in wetter years (higher Apr1SWC) and higher ANPP levels in drier years (lower Apr1SWC) (Table 1). At the xeric site, ANPP was generally lowest in the 2 wettest years of 1995 and 1998 and highest in the second and third driest years of 1999 and 2000. ANPP was lowest at the mesic site in the wettest years of 1995 and 1998 but did not vary greatly after the first year. ANPP was greatest at the hydric site in the drier years of 1994, 1996, and 2000 and was lowest in the wetter years of 1995 and 1998.

Models with random effects for plot and year, nested within meadow type, fit the data as well as or better than models without one or both random effects $\left(\Delta \mathrm{AIC}_{c}>2\right)$, and these random effects were included in all subsequent comparisons of fixed effects. The data most strongly support the model containing meadow type, AprlSWC ${ }_{\mathrm{cy}}, \mathrm{TDD}_{\mathrm{s}-\mathrm{h}}$, and interactions of Type*AprlSWC ${ }_{c y}$ and Type* $\mathrm{TDD}_{\mathrm{s}-\mathrm{h}}$. This model has over 40 times the support of the second-best model containing SFD instead of $\mathrm{TDD}_{\mathrm{s}-\mathrm{h}}$ (ratio of Akaike weights: $0.964 \div 0.023=41.9$; Table 2 ). This model also explains substantially more variation, compared with the null model, than the second-best model $\left(\mathrm{R}^{2}=0.525\right.$ vs. 0.330 ; Table 2). The remaining models, including the null model of no climatic effects, have considerably less support. The best models did not include previous-year measures of the climatic variables.

Applying the Apr $1 \mathrm{SWC}_{\mathrm{cy}}$ and $\mathrm{TDD}_{\mathrm{s}-\mathrm{h}}$ model, we estimated ANPP using the equation 
TABLE 2. Analysis of covariance models for aboveground net primary productivity (ANPP) of mountain meadows within Yosemite National Park, California, 1994-2000, with corresponding -2 log likelihood, number of parameters (K, including intercept, plot, and variance parameters), corrected Akaike's information criterion ( $\left.\mathrm{AIC}_{c}\right)$ score, differences among $\mathrm{AIC}_{c}$ scores $\left(\Delta \mathrm{AIC}_{c}\right)$, and Akaike weights $(w)$. ANCOVA contains random effects, namely random plot and year effects nested within meadow type. Vertical bar denotes that interaction and main effects are inclusive. Models are ranked by $\Delta \mathrm{AIC}_{c}$, which indicates the difference between each model and the best model (lowest $\mathrm{AIC}_{c}$ denotes rank 1 ). $\mathrm{R}^{2}$ values represent proportion of variation explained by the model (i.e., with weather covariates) when compared to the null model that is based on meadow type and random plot effects only.

\begin{tabular}{|c|c|c|c|c|c|c|c|}
\hline Rank & Model & $-2 \log L$ & $\mathrm{~K}$ & $\mathrm{AIC}_{c}$ & $\Delta \mathrm{AIC}_{c}$ & $w$ & $\mathrm{R}^{2}$ \\
\hline 1 & Type | Apr1SWC ${ }_{c y}+$ Type $\mid$ TDD $_{s-h}$ & -55.83 & 12 & -26.96 & 0.00 & 0.964 & 0.525 \\
\hline 2 & Type $\mid$ Apr1SWC ${ }_{\mathrm{cy}}+$ Type SFD & -48.40 & 12 & -19.52 & 7.44 & 0.023 & 0.330 \\
\hline 3 & Type | SFD + Type | TDD $_{s-h}$ & -46.69 & 12 & -17.82 & 9.14 & 0.010 & 0.276 \\
\hline 4 & Null model (Type effect only) & -26.73 & 6 & -13.53 & 13.43 & 0.001 & 0.000 \\
\hline 5 & Type | Apr1SWC $\mathrm{Cy}_{\mathrm{py}}+$ Type $\mid \mathrm{TDD}_{\mathrm{py}}$ & -42.32 & 12 & -13.44 & 13.52 & 0.001 & 0.165 \\
\hline
\end{tabular}

TABLE 3. Estimates, standard errors (SE), and $90 \%$ confidence limits (CLs) for the coefficients $\alpha, \beta_{1}$, and $\beta_{2}$ in the model $\ln (\mathrm{ANPP})=\alpha+\beta_{1} \times \mathrm{TDD}_{\mathrm{s}-\mathrm{h}}+\beta_{2} \times \mathrm{Apr}_{\mathrm{SWC}}$, corresponding to the Intercept, Apr1SWC $\mathrm{Cy}_{\mathrm{cy}}$, and TDD $\mathrm{T}-\mathrm{h}$ effects, respectively, for each of 3 meadows. Estimates of $100 \beta$ are displayed for $A_{p r} 1 S_{W C}$ and $\mathrm{TDD}_{s-\mathrm{h}}$ to express the change in mean ANPP, on the natural-log scale, per 100 units of covariate increase (i.e., $100 \mathrm{~mm}$ increase in snow water content or $100{ }^{\circ} \mathrm{C}$ increase in thawing degree days). The estimated percent change in mean ANPP per 100 units of covariate increase is related to the model coefficient as $\exp (100 \beta)-100 \%$.

\begin{tabular}{|c|c|c|c|c|c|}
\hline \multirow[b]{2}{*}{ Variable } & \multirow[b]{2}{*}{ Meadow type } & \multicolumn{2}{|c|}{ Model coefficient $(100 \beta)$} & \multicolumn{2}{|c|}{ Percent change $(\%)$} \\
\hline & & Estimate (SE) & $90 \% \mathrm{CLs}$ & Estimate (SE) & $90 \%$ CLs \\
\hline \multirow[t]{3}{*}{ Intercept } & Xeric & $5.17(0.29)$ & $4.65,5.68$ & - & - \\
\hline & Mesic & $5.41(0.66)$ & $4.23,6.58$ & - & - \\
\hline & Hydric & $5.12(0.79)$ & $3.72,6.50$ & - & - \\
\hline TDD $_{\text {s-h }}$ effect (per & Xeric & $-0.030(0.015)$ & $-0.058,-0.003$ & $-3.0(1.5)$ & $-5.6,-0.3$ \\
\hline \multirow{2}{*}{$100^{\circ-} \mathrm{C}$ increase) } & Mesic & $0.059(0.065)$ & $-0.057,0.174$ & $6.0(6.9)$ & $-5.5,19.0$ \\
\hline & Hydric & $0.063(0.046)$ & $-0.018,0.144$ & $6.5(4.9)$ & $-1.8,15.4$ \\
\hline Apr1SWC $_{\mathrm{cy}}$ effect (per & Xeric & $-0.077(0.025)$ & $-0.122,-0.032$ & $-7.4(2.3)$ & $-11.5,-3.1$ \\
\hline \multirow{2}{*}{$100 \mathrm{~mm}$ increase) } & Mesic & $-0.098(0.027)$ & $-0.146,-0.049$ & $-9.3(2.5)$ & $-13.6,-4.8$ \\
\hline & Hydric & $-0.032(0.021)$ & $-0.069,0.006$ & $-3.1(2.1)$ & $-6.7,0.6$ \\
\hline
\end{tabular}

$\ln (\mathrm{ANPP})=\alpha+\beta_{1} \times \mathrm{TDD}_{\mathrm{s}-\mathrm{h}}+\beta_{2} \times \mathrm{AprlSWC}_{\mathrm{cy}}$,

where the coefficients $\alpha, \beta_{1}$, and $\beta_{2}$ have separate values by meadow (Table 3 ). $\mathrm{TDD}_{\mathrm{S}-\mathrm{h}}$ was negatively associated with ANPP in the xeric meadow but was not significantly associated with ANPP in the mesic and hydric meadows, although the nonsignificant relationships trended in a positive direction. The average change in ANPP for the xeric meadow was estimated at $3 \%$ per $100 \mathrm{TDD}_{\mathrm{s}-\mathrm{h}}$ increase. Although ANPP increased in mesic and hydric meadows at an estimated 6\% per $100 \mathrm{TDD}_{\mathrm{s}-\mathrm{h}}$ increase, these associations were not significant $(90 \%$ confidence intervals overlapped zero; Table 3). There was a significant and similarly strong negative association of $\mathrm{SWC}_{\mathrm{cy}}$ with ANPP on the xeric and mesic sites. Mean ANPP decreased at an estimated rate of $7 \%$ (90\% CI: $3 \%-12 \%)$ and 9\% (90\% CI: 5\%-14\%) per $100 \mathrm{~mm}$ increase in snow water content for xeric and mesic sites, respectively, whereas the estimated change for the hydric site was only half as large and not significantly different than zero.

\section{Discussion}

Our ANPP estimates are comparable in magnitude and variability to other values from the Sierra Nevada for the same meadow types (Klikoff 1965, Ratliff 1985). Annual ANPP varied according to spring snow water content and seasonal temperatures, and these effects varied by meadow type. Lower snow water content was associated with increased ANPP in the xeric and mesic meadows but not the hydric meadow. As expected, the hydric meadow was less sensitive to changes in mean annual moisture input than the drier meadow, although the large intra-annual variation in ANPP contributed to the lack of significant relationships with climatic variables. Under wetter spring conditions, ANPP may be limited by 
anaerobic conditions that limit microbial activity and availability of soil nutrients (Schuur and Matson 2001). The negative association of warmer temperatures and ANPP at the xeric site suggests that increased energy, resulting in higher evaporation rates, shortens the duration of sufficient soil moisture. These patterns are consistent with studies showing increased ANPP with increased temperature in other subalpine to alpine meadow systems (Scott and Billings 1964) and arctic tundra (Hollister et al. 2005, Epstein et al. 2008), as well as warming experiments that stimulated nutrient availability (Rustad et al. 2001).

Our results did not support the inclusion of climate variables for the previous year. Walker et al. (1994) found that ANPP was most closely related to previous-year precipitation in dry and moist alpine meadows in the Colorado Rocky Mountains, but also found that in wet meadows, the current-year soil moisture, snow-free date, and current-season precipitation were more closely related to ANPP. However, their measures of precipitation were for the growing season and were not comparable to spring snow water content. Also, although the path analysis results of Walker et al. (1994) were significant, previous-year precipitation explained only $25 \%$ and $33 \%$ of the variation in ANPP for the moist and dry meadows, respectively.

Our results suggest that snow water content and degree days are independent contributors to ANPP in these meadows. Potential responses to climate inputs might be additive, as when snow water amounts and degree day values both increase or decrease ANPP (mesic and hydric meadows), or counteract when ANPP responses to snow water inputs are reversed by responses to degree day inputs (xeric meadows). For example, conditions in 1994 were similar to predicted average conditions under conservative climate change estimates (Emissions Scenario B1 for comparable elevations in Hayhoe et al. 2004). In that year, the Apr1SWC was 53\%-68\% of the long-term mean (available SWC record is 25 years), TDD was $16 \%$ greater than the long-term mean, and the SFD was 1-3 weeks earlier than the long-term mean. Under these drier and warmer conditions, the corresponding ANPP was $73 \%$ greater than the 7-year mean at the mesic meadow and $23 \%$ greater at the hydric meadow (positive ANPP responses to warmer and drier). However, the ANPP in the xeric meadow did not differ from the longterm mean because the expected increase in ANPP with warmer temperatures was counterbalanced by the expected decrease in ANPP under the drier conditions. These relationships suggest that, under projected warmer and drier conditions, ANPP will increase in mesic meadows but remain unchanged in xeric meadows because declines associated with increased temperatures would offset the increases from decreased snow water content.

\section{ACKNOWLEDGMENTS}

This work was supported by the Yosemite Conservancy, the USDA Forest Service, the Aldo Leopold Wilderness Research Institute, the Student Conservation Association, and the National Park Service. Manuscript production was supported by the U.S. Geological Survey, Status \& Trends Program. We are grateful for field assistance from Vanessa Barger, Mary Ellen Colberg, Marie Denn, Susan Elliott, Sunny Fross, Michael Hentz, Katie Hughes, Vanessa Johnson, Jolie Kates, Lindsey Kiesz, Andrew McCall, Holly Nielsen, Kasmira Rak, Carmela Rios, Renee Rivers, Samuel Simkin, John Staight, Wendy Stevens, Auric Thole, and Margaret Willits. We are also grateful to Thomas Stohlgren and 2 anonymous reviewers for helpful reviews of the manuscript. Any use of trade names is for descriptive purposes only and does not imply endorsement by the U.S. Government.

\section{Literature Cited}

Barnett, T.P., D.W. Pierce, H.G. Hidalgo, C. Bonfils, B.D. Santer, T. Das, G. Gala, A.W. WoOd, T. Nozawa, A.A. Mirin, ET AL. 2008. Human-induced changes in the hydrology of the western United States. Science 319:1080-1083.

BiLlings, W.D., AND L.C. BLISs. 1959. An alpine snowbank environment and its effects on vegetation, plant development, and productivity. Ecology 40:388-397.

Bowman, W.D., T.A. Theodose, and M.C. FISK. 1995. Physiological and production responses of plant growth forms to increases in limiting resources in alpine tundra: implications for differential community response to environmental change. Oecologia 101:217-227.

Burnham, K.P., And D.R. Anderson. 2002. Model selection and multimodel inference: a practical information-theoretic approach. 2nd edition. Springer-Verlag, New York, NY

[CDWR] California Department of Water Resources. 2011. California Data Exchange Center [online]. 
California Department of Water Resources; [cited 26 August 2011]. Available from: http://cdec.water .ca.gov/.

Chapin, F.S., III, E. Rincon, and P. Huante. 1993. Environmental responses of plants and ecosystems as predictors of the impact of global change. Journal of Biosciences 18:515-524.

Cole, D.N., J.W. van Wagtendonk, M.P. McClaran, P.E. Moore, AND N.K. MCDougaLd. 2004. Response of mountain meadows to grazing by recreational pack stock. Journal of Range Management 57:153-160.

Epstein, H.E., D.A. Walker, M.K. Raynolds, G.J. Jia, AND A.M. KELLEY. 2008. Phytomass patterns across a temperature gradient of the North American arctic tundra. Journal of Geophysical Research 113: ARTN G03S02.

Fisk, M.C., S.K. Schmidt, and T.R. Seastedt. 1998. Topographic patterns of above- and belowground production and nitrogen cycling in Alpine tundra. Ecology 79:2253-2266.

GaLen, C., and M.L. Stanton. 1993. Short-term responses of alpine buttercups to experimental manipulations of growing-season length. Ecology 74:1052-1058.

Hayhoe, K., D. Cayan, C.B. Field, P.C. Frumhoff, E.P. Maurer, N.L. Miller, S.C. Moser, S.H. SchneIDer, K.N. Cahill, E.E. Cleland, et al. 2004. Emissions pathways, climate change, and impacts on California. PNAS 101:12422-12427.

HobBie, S.E., AND F.S. ChapIn, III. 1998. The response of tundra plant biomass, aboveground production, nitrogen, and $\mathrm{CO}_{2}$ flux to experimental warming. Ecology 79:1526-1544.

Hollister, R.D., P.J. Webber, and C. Bay. 2005. Plant response to temperature in northern Alaska: implications for predicting vegetation change. Ecology 86:1562-1670

Holmquist, J.G., J.R. Jones, J. Schmidt-Gengenbach, L.F. Pierotti, AND J.P. Love. 2011. Terrestrial and aquatic macroinvertebrate assemblages as a function of wetland type across a mountain landscape. Arctic, Antarctic, and Alpine Research 43:568-584.

Hruby, T. 2009. Developing rapid methods for analyzing upland riparian functions and values. Environmental Management 43:1219-1243.

Hsu, J.S., J. Powell, AND P.B. AdLer. 2012. Sensitivity of mean annual primary production to precipitation. Global Change Biology 18:2246-2255.

KLikofF, L.G. 1965. Microenvironmental influence on vegetational pattern near timberline in the central Sierra Nevada. Ecological Monographs 35:187-211.

LitTell, R.C., G.A. Milliken, W.W. Stroup, and R.D. Wolfinger. 1996. SAS System for Mixed Models. SAS Institute, Inc., Cary, NC.

Maurer, E.P., I.T. Stewart, C. Bonfils, P.B. Duffy, and D.R. CAYAN. 2007. Detection, attribution, and sensitivity of trends toward earlier streamflow in the Sierra Nevada. Journal of Geophysical Research 112: D11118, http://dx.doi.org/10.1029/2006JD008088

Morton, M.L., AND M.E. PEREYRA. 2010. Habitat use by Yosemite toads: life history traits and implications for conservation. Herpetological Conservation and Biology 5:388-394.

Mote, P.W., A.F. Hamlet, M.P. Clark, and D.P. LettenMAIER. 2005. Declining mountain snowpack in western North America. Bulletin of the American Meteorological Society 86:39-49.

NatureServe. 2011. NatureServe Explorer: an online encyclopedia of life. [Cited 26 August 2011]. Available from: http://www.natureserve.org/explorer/.

Ratliff, R.D. 1982. A meadow site classification for the Sierra Nevada, California. General Technical Report PSW-60, USDA Forest Service.

1985. Meadows in the Sierra Nevada of California: state of knowledge. General Technical Report PSW-84, USDA Forest Service, Pacific Southwest Research Station, Berkeley, CA.

Roche, L.M., B. Allen-Diaz, D.J. Eastburn, and K.W. TATE. 2012. Cattle grazing and Yosemite toad (Bufo canorus Camp) breeding habitat in Sierra Nevada meadows. Rangeland Ecology and Management 65: $56-65$.

Rustad, L.E., J.L. Campbell, G.M. Marion, R.J. Norby, M.J. Mitchell, A.E. Hartley, J.H.C. Cornelissen, J. Gurevitch, AND GCTE-NEWS. 2001. A metaanalysis of the response of soil respiration, net nitrogen mineralization, and aboveground plant growth to experimental ecosystem warming. Oecologia 126: $543-562$.

SAS Institute, InC. 2007. SAS OnlineDoc ${ }^{\circledR}$ 9.2. SAS Institute, Inc., Cary, NC.

SchuUr, E.A., AND P.A. Matson. 2001. Net primary productivity and nutrient cycling across a mesic to wet precipitation gradient in Hawaiian montane forest. Oecologia 128:431-442.

ScotT, D., AND W.D. Billings. 1964. Effects of environmental factors on standing crop and productivity of an alpine tundra. Ecological Monographs 34: 243-270.

Smith, R.D., A. Ammann, C. Bartoldus, and M.M. BrinSON. 1995. An approach for assessing wetland functions using hydrogeomorphic classification, reference wetlands, and functional indices. Wetlands Research Program Technical Report WRP-DE-9, U.S. Army Corps of Engineers Waterways Experiment Station, Vicksburg, MS.

Walker, M.D., P.J. Webber, E.H. Arnold, and D. EBERT-May. 1994. Effects of interannual climate variation on aboveground phytomass in alpine vegetation. Ecology 75:393-408.

[WRCC] Western Regional Climate Center. 2011. Historical climate information: Yosemite Park Headquarters (049855). [Cited 22 September 2011]. Available from: http://www.wrcc.dri.edu/index.html

Zuur, A.F., E.N. IENo, N.J. Walker, A.A. Saveliev, and G.M. Sмiтh. 2009. Mixed effects models and extensions in ecology with R. Springer Science + Business Media, LLC, New York, NY.

Received 19 November 2012 Accepted 10 June 2013 